\title{
AIP expression in sporadic somatotropinomas is a predictor of the response to octreotide LAR therapy independent of SSTR2 expression
}

\section{Dear Editor}

Somatostatin receptor ligands (SRL) are currently the cornerstone of the medical treatment of acromegalic patients (Melmed et al. 2009). Disease control may be achieved by currently available SRL therapy in $\sim 30$ $40 \%$ of patients in prospective clinical trials (Mercado et al. 2007). Considering the present accessibility of the diverse classes of drugs and their elevated costs, it would be valuable to identify predictive markers for the patients who are more likely to respond to SRL therapy.

Somatostatin receptor subtype 2 (SSTR2) expression seems to represent the best predictor of the response to SRL (Colao et al. 2011). Indeed, some studies have shown a positive correlation between the expression of SSTR2 mRNA and protein and the clinical response to SRL (Taboada et al. 2008, Wildemberg et al. 2012).

Daly et al. (2010) have previously observed that acromegalic patients with germline mutations in the aryl hydrocarbon receptor-interacting protein $(A I P)$ gene exhibited a worse response to SRL therapy as compared to patients without these mutations. In addition, it has been previously demonstrated that sporadic somatotropinomas can present low AIP protein expression even in the absence of mutations (Jaffrain-Rea et al. 2009). Based on these data, in the current study, we sought to evaluate whether AIP expression is a predictor of octreotide LAR (OCTLAR) response independent of SSTR2 expression in patients with sporadic somatotropinomas without $A I P$ mutations.

Acromegalic patients consecutively operated on between 2006 and 2010 and not cured by surgical resection were included in the study. All patients signed informed consent forms before entering the study. Local ethics committee approved the study.

Exclusion criteria included previous radiotherapy for pituitary adenoma treatment, presence of AIP mutation and/or a history of medical treatment with SRL before surgery. Biochemical assessment was performed 3 months after surgery by oral glucose tolerance test (OGTT) and evaluations of IGF1 levels. Patients were considered non-cured based on nonsuppressible GH levels on OGTT and plasma IGF1 levels higher than those of age-matched normal subjects. Medical therapy with OCT-LAR was started at a dose of $20 \mathrm{mg}$ every 4 weeks, and the dose was increased to $30 \mathrm{mg}$ in patients with non-controlled disease after 3 months of therapy. The efficacy of medical therapy was evaluated during the last patient visit. Patients were considered to have non-controlled disease if they had plasma IGF1 levels greater than those of age-matched normal subjects or basal GH levels $>1.0 \mathrm{ng} / \mathrm{ml}$ after at least 6 months of treatment with OCT-LAR at a dosage of $30 \mathrm{mg}$.

The AIP and SSTR2 expressions were analyzed through immunohistochemistry in paraffin-embedded tissue sections as previously described (Kasuki Jomori de Pinho et al. 2011, Wildemberg et al. 2011). For SSTR2, both membrane-bound and intracytoplasmic immunopositivity were considered for staging. Tumors were staged according to the percentage of stained cells: $0(<25 \%$ stained cells - low expression $)$ or 1 ( $\geq 25 \%$ - high expression), as previously validated by our group (Wildemberg et al. 2011). For the estimate of cytoplasmic AIP immunostaining, slides were scored for pattern (diffuse (score 2) or patchy (score 1)) and for intensity (strong (score 3), moderate (score 2) and weak (score 1)), and the final score was calculated by multiplying the two scores (pattern and intensity). Scores of 0 (no expression), 1 and 2 were considered low AIP expression.

The statistical analysis was performed using SPSS version 16.0 for Windows (SPSS, Inc., Chicago, IL, USA). The results were reported as median values (minimum-maximum). The Mann-Whitney non-parametric test, the Fisher exact test and $\chi^{2}$ test were used as appropriate. For multivariate analysis, binary 
logistic regression was performed. $P$ values $<0.05$ were considered statistically significant.

Thirty-five samples from acromegalic patients (21 women) were included. The median age at diagnosis was 43 years (range 23-60 years). Thirty-two out of 35 tumors $(91.4 \%)$ were macroadenomas. Thirteen tumors $(37.1 \%)$ were mixed adenomas (positive staining for $\mathrm{GH}$ and prolactin), and the others were pure $\mathrm{GH}$ somatotropinomas. The median GH and IGF1 levels before OCT-LAR treatment were $14 \mathrm{ng} / \mathrm{ml}$ and $260 \%$ of the upper limit of normal range (ULNR), respectively.

All somatotropinomas expressed SSTR2A, with high expression observed in 29 tumors $(83 \%)$. Both membrane and cytoplasmic staining of SSTR2A were observed (Fig. 1). AIP immunostaining was positive in all tumors, with 18 samples (51\%) exhibiting low expression (Fig. 1). There was no difference in age, gender, hormonal staining, treatment duration, baseline $\mathrm{GH}$ or IGF1 levels between patients harboring somatotropinomas with low or high SSTR2A expression and between those with low or high AIP expression (Table 1). Additionally, no difference was observed in the SSTR2A expression levels between adenomas with low or high AIP expression.

In fifteen patients (43\%), OCT-LAR therapy resulted in controlled disease. There was no difference between basal GH, IGF1, gender, age or hormonal staining between patients with controlled and noncontrolled disease states. Treatment duration ranged from 9 to 57 months (median 28 months).
None of the patients $(n=6)$ with SSTR2A expression lower than $25 \%$ (score 0 ) were controlled with OCT-LAR, whereas 15 out of $29(52 \%)$ patients classified as score 1 reached a biochemically controlled disease state $(P=0.024)$. Four out of 18 tumors $(22 \%)$ with low AIP expression were controlled with OCTLAR treatment, whereas 11 out of 17 (65\%) patients with high AIP expression reached a biochemically controlled disease state $(P=0.013)$. The control rate in the patients who presented with high AIP and SSTR2 expression was $79 \%$ (11 out of 14). The use of both tests to predict control rates yields a sensitivity of $73 \%$, a specificity of $85 \%$, a positive predictive value of $79 \%$, a negative predictive value of $81 \%$ and an accuracy of $80 \%$. After multivariate analysis, SSTR2A $(P=0.02)$ and AIP $(P=0.02)$ remained statistically significant predictors of disease control.

Germline mutations in the AIP gene are found in familial and early-onset pituitary adenoma setting, with a predomination of somatotropinomas in the mutated gene cases (Igreja et al. 2010, Tichomirowa et al. 2011). The AIP-mutated patients have smaller decreases in GH and IGF1 levels as well as less tumor shrinkage with SRL therapy (Leontiou et al. 2008, Daly et al. 2010, Pinho et al. 2010). These data indicate that AIP may play a role in the mechanism of response to SRL. Indeed, Chahal et al. (2009) have shown that treatment of GH3 cell lines with octreotide increased the AIP protein expression at 9 and $12 \mathrm{~h}$. They also observed that patients treated with lanreotide prior to surgery exhibited tumors with higher AIP expression
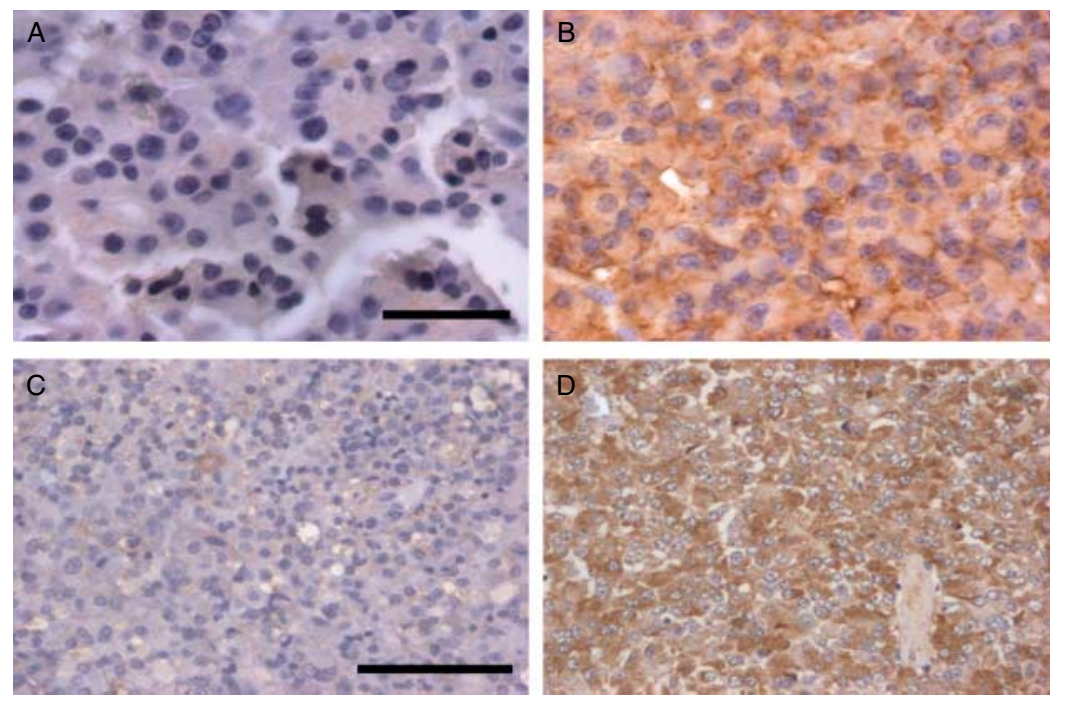

Figure 1 Examples of somatostatin receptor subtype 2 (SSTR2) and aryl hydrocarbon receptor-interacting protein (AIP) expression: (A) low SSTR2 expression ( $<25 \%$ of immunostained cells). (B) High SSTR2 expression ( $\geq 25 \%$ of immunostained cells). Scale bar: $500 \mu \mathrm{m}$. (C) Low AIP expression (score 1 - patchy and weak). (D) High AIP expression (score 6 - diffuse and strong). Scale bar: $1000 \mu \mathrm{m}$. 
Table 1 Patient characteristics according to somatostatin receptor subtype 2 (SSTR2) and aryl hydrocarbon receptor-interacting protein (AIP) expression

\begin{tabular}{|c|c|c|c|c|c|c|}
\hline & High SSTR2 & Low SSTR2 & $P$ value & High AIP & Low AIP & $P$ value \\
\hline Age & $46(23-60)$ & $36(28-50)$ & 0.403 & $43(23-60)$ & $45(24-55)$ & 0.832 \\
\hline Female & $58.6 \%$ & $66.6 \%$ & 0.544 & $61 \%$ & $58.8 \%$ & 0.582 \\
\hline $\begin{array}{l}\text { Mixed tumor } \\
(\mathrm{GH} / \mathrm{PRL})\end{array}$ & $37.9 \%$ & $33.3 \%$ & 0.608 & $41.1 \%$ & $33.3 \%$ & 0.448 \\
\hline $\begin{array}{l}\text { Treatment } \\
\text { duration } \\
\text { (months) }\end{array}$ & $29(9-57)$ & $25(12-35)$ & 0.848 & $29(12-57)$ & $24(9-48)$ & 0.568 \\
\hline Baseline GH & $12.6(1.1-112)$ & $19.4(10-102)$ & 0.133 & $29.6(1.1-102)$ & $19.6(2.2-112)$ & 0.322 \\
\hline $\begin{array}{c}\text { Baseline IGF1 } \\
(\% \text { LNR })\end{array}$ & $229(128-457)$ & $294(203-415)$ & 0.145 & 214 (128-382) & 265 (137-457) & 0.135 \\
\hline
\end{tabular}

Results are presented as median (min-max). ULNR, upper limit of normal range.

than those of untreated patients. These results reinforce the potential role of AIP in the mechanism of SRL response in somatotropinomas.

In sporadic somatotropinomas, germline $A I P$ mutations have been described in a small proportion of cases (mainly young patients), and no somatic mutations have been found to date (Raitila et al. 2007, Tichomirowa et al. 2011). However, a subset of sporadic tumors present with low AIP protein expression (Jaffrain-Rea et al. 2009, Kasuki Jomori de Pinho et al. 2011) even in the absence of mutations, as in our present series. In addition, our group has recently demonstrated that low AIP expression is associated with tumor invasiveness in somatotropinomas (Kasuki Jomori de Pinho et al. 2011).

No previous study has evaluated whether the expression of AIP may be a predictor of response to OCT-LAR therapy in sporadic somatotropinomas without AIP mutations. Here, we report that patients with low AIP expression are less likely to achieve disease control with OCT-LAR treatment. In addition, we demonstrate that AIP expression is a predictor of disease control independent of SSTR2 expression. Further, when both AIP and SSTR2 expression are used in combination, it is possible to predict the response to therapy with enhanced accuracy. Thus, the use of both markers may represent a useful tool in the clinical treatment decision.

In our study, we excluded those patients who were treated with SRL before surgery because SRL can increase the AIP protein expression (Chahal et al. 2009) and thus introduce a bias in the study.

The mechanism of resistance to OCT-LAR in patients with low AIP expression has not been described. In the present study, the expression of SSTR2 is not responsible for this decreased response to therapy, as SSTR2 expression does not differ between adenomas with high or low AIP expression. It is probable that AIP has a direct role in the response to OCT-LAR, as AIP expression increases in cell lines treated with octreotide (Chahal et al. 2009). However, further studies are necessary to clarify the exact mechanism(s).

In conclusion, our study suggests that AIP expression in sporadic somatotropinomas without AIP mutations is a predictor of acromegaly control with OCT-LAR treatment independent of SSTR2 expression. In addition, when both markers are used in conjunction, it is possible to predict patient responses to OCT-LAR therapy with a higher accuracy than when each one is used individually.

Leandro Kasuki ${ }^{1,3}$ Leonardo Vieira Neto ${ }^{1,4}$ Luiz Eduardo A Wildemberg ${ }^{1}$ Leandro Machado Colli ${ }^{5}$ Margaret de Castro 5 Christina M Takiya ${ }^{2}$ Mônica R Gadelha ${ }^{1}$

${ }^{1}$ Endocrinology Unit, Clementino Fraga Filho University Hospital and ${ }^{2}$ Cell Pathology Laboratory, Biomedics Science Institute, Federal University of Rio de Janeiro, Rio de Janeiro, Brazil

${ }^{3}$ Endocrinology Unit, Bonsucesso Federal Hospital, Rio de Janeiro, Brazil

${ }^{4}$ Endocrinology Unit, Lagoa Federal Hospital, Rio de Janeiro, Brazil

${ }^{5}$ Endocrinology Laboratory, Ribeirão Preto Medical School, São Paulo University, Ribeirão Preto, Brazil 
(Correspondence should be addressed to M R Gadelha who is now at Neuroendocrinology Research Center - Endocrinology Unit, Clementino Fraga Filho University Hospital, Federal University of Rio de Janeiro, Rua Professor Rodolpho Paulo Rocco, 255, sala 9F, Ilha do Fundão, 21941-913 Rio de Janeiro, Brazil; Email: mgadelha@hucff.ufrj.br)

\section{Declaration of interest}

M R Gadelha has received grant support and speaker fee from Novartis Biociências S.A and Pfizer.

\section{Funding}

This work was supported by grants from Coordenação de Aperfeiçoamento de Pessoal de Nível Superior (CAPES) (L Kasuki, L Vieira Neto, L E A Wildemberg).

\section{Acknowledgements}

The authors would like to thank Prof. Márta Korbonits for performing AIP mutation analysis of some patients.

\section{References}

Chahal HS, Ansorge O, Karavitaki KD, Leontiou CA, Carlsen E, Wass JAH, Grossman AB \& Korbonits M 2009 Somatostatin analogue treatment increases AIP protein expression in somatotroph tumors from patients with acromegaly and in GH3 cells in vitro. In 91 Annual Meeting Endo 2009. Washington/EUA.

Colao A, Auriemma RS, Lombardi G \& Pivonello R 2011 Resistance to somatostatin analogs in acromegaly. Endocrine Reviews 32 247-271. (doi:10.1210/er.20100002)

Daly AF, Tichomirowa MA, Petrossians P, Heliovaara E, Jaffrain-Rea ML, Barlier A, Naves LA, Ebeling T, Karhu A, Raappana A et al. 2010 Clinical characteristics and therapeutic responses in patients with germ-line AIP mutations and pituitary adenomas: an international collaborative study. Journal of Clinical Endocrinology and Metabolism 95 E373-E383. (doi:10.1210/jc.20092556)

Igreja S, Chahal HS, King P, Bolger GB, Srirangalingam U, Guasti L, Chapple JP, Trivellin G, Gueorguiev M, Guegan $\mathrm{K}$ et al. 2010 Characterization of aryl hydrocarbon receptor interacting protein (AIP) mutations in familial isolated pituitary adenoma families. Human Mutation 31 950-960. (doi:10.1002/humu.21292)

Jaffrain-Rea ML, Angelini M, Gargano D, Tichomirowa MA, Daly AF, Vanbellinghen JF, D'Innocenzo E, Barlier A, Giangaspero F, Esposito V et al. 2009 Expression of aryl hydrocarbon receptor (AHR) and AHR-interacting protein in pituitary adenomas: pathological and clinical implications. Endocrine-Related Cancer 16 1029-1043. (doi:10.1677/ERC-09-0094)

Kasuki Jomori de Pinho L, Vieira Neto L, Wildemberg LE Armondi, Gasparetto EL, Marcondes J, de Almeida Nunes B, Takiya CM \& Gadelha MR 2011 Low aryl hydrocarbon receptor-interacting protein expression is a better marker of invasiveness in somatotropinomas than Ki-67 and p53. Neuroendocrinology 94 39-48. (doi:10. 1159/000322787)

Leontiou CA, Gueorguiev M, van der Spuy J, Quinton R, Lolli F, Hassan S, Chahal HS, Igreja SC, Jordan S, Rowe J et al. 2008 The role of the aryl hydrocarbon receptorinteracting protein gene in familial and sporadic pituitary adenomas. Journal of Clinical Endocrinology and Metabolism 93 2390-2401. (doi:10.1210/jc.2007-2611)

Melmed S, Colao A, Barkan A, Molitch M, Grossman AB, Kleinberg D, Clemmons D, Chanson P, Laws E, Schlechte J et al. 2009 Guidelines for acromegaly management: an update. Journal of Clinical Endocrinology and Metabolism 94 1509-1517. (doi:10.1210/ jc.2008-2421)

Mercado M, Borges F, Bouterfa H, Chang TC, Chervin A, Farrall AJ, Patocs A, Petersenn S, Podoba J, Safari M et al. 2007 A prospective, multicentre study to investigate the efficacy, safety and tolerability of octreotide LAR (long-acting repeatable octreotide) in the primary therapy of patients with acromegaly. Clinical Endocrinology 66 859-868. (doi:10.1111/j.1365-2265.2007.02825.x)

Pinho LK, Vieira Neto L, Wildemberg LE, Moraes AB, Takiya CM, Frohman LA, Korbonits M \& Gadelha MR 2010 Familial isolated pituitary adenomas experience at a single center: clinical importance of AIP mutation screening. Arquivos Brasileiros de Endocrinologia e Metabologia 54 698-704. (doi:10.1590/S000427302010000800006)

Raitila A, Georgitsi M, Karhu A, Tuppurainen K, Makinen MJ, Birkenkamp-Demtroder K, Salmenkivi K, Orntoft TF, Arola J, Launonen V et al. 2007 No evidence of somatic aryl hydrocarbon receptor interacting protein mutations in sporadic endocrine neoplasia. Endocrine-Related Cancer 14 901-906. (doi:10.1677/ERC-07-0025)

Taboada GF, Luque RM, Neto LV, Machado Ede O, Sbaffi BC, Domingues RC, Marcondes JB, Chimelli LM, Fontes R, Niemeyer P et al. 2008 Quantitative analysis of somatostatin receptor subtypes (1-5) gene expression levels in somatotropinomas and correlation to in vivo hormonal and tumor volume responses to treatment with octreotide LAR. European Journal of Endocrinology 158 295-303. (doi:10.1530/EJE-07-0562)

Tichomirowa MA, Barlier A, Daly AF, Jaffrain-Rea ML, Ronchi C, Yaneva M, Urban JD, Petrossians P, Elenkova A, Tabarin A et al. 2011 High prevalence of AIP gene mutations following focused screening in young patients with sporadic pituitary macroadenomas. European Journal of Endocrinology 165 509-515. (doi:10.1530/ EJE-11-0304) 
Wildemberg LE, Vieira Neto L, Costa DF, Nasciutti LE, Takiya CM, Alves LM \& Gadelha MR 2011 Validation of immunohistochemistry for somatostatin receptor subtype $2 \mathrm{~A}$ in human somatotropinomas: comparison between quantitative real time RT-PCR and immunohistochemistry. Journal of Endocrinological

Investigation. (doi:10.3275/7906)
Wildemberg LE, Vieira Neto L, Costa DF, Nasciuti LE, Takiya CM, Alves LM, Rebora A, Minuto F, Ferone D \& Gadelha MR 2012 Low somatostatin receptor subtype 2, but not dopamine receptor subtype 2 , expression predicts the lack of biochemical response of somatotropinomas to treatment with somatostatin analogs. Journal of Endocrinological Investigation. (doi:10.3275/8305) 